\title{
ANALISIS INVESTASI, PENGELUARAN PEMERINTAH DAN PERTUMBUHAN EKONOMI TERHADAP KESEMPATAN KERJA DI PROPINSI NUS A TENGGARA BARAT
}

\author{
O le h: \\ Muammil Sun'an*) \\ Endang Astuti ${ }^{* *}$ )
}

\begin{abstract}
Employment or unemployment indeed is a global problem faced by almost all countries in the world, developing and developed industrial countries are facing same problem. The intensity of problem might be different from among the countries due to difference influence factors, such as economic growth, investment or government expenditure directly influence on creating employment. High economic growth rate and investment will increase employment. While changes in government expenditures is too much depended on proportion or budget allocation for development finance.

Research findings in the province of Nusa Tenggara Barat indicate that economic growth and investment influence on the increasing employment. Agricultural, industrial and services sectors bring positive influence through increasing investment values on creating employment, while economic growth doesn't influence on employment in agricultural sector, instead its influence on industrial and services sectors. Expansive fiscal policy brings negative influence on employment in industrial sector, but however, on the other side it has positive influence on employment in services sector. Employment in districts / towns in the province of Nusa Tenggara Barat influenced by economic growth and government expenditure.
\end{abstract}

Keywords : employment, investment, economic growth and government expenditure.

\section{PENDAHULUAN}

Latar Belakang

Kesempatan kerja pada dasarnya merupakan masalah yang dihadapi semua negara, baik negara berkembang maupun negara maju. Walaupun intensitas dari masalah tersebut mungkin sekali berbeda karena adanya perbedaan pada faktor-faktor yang mempengaruhi seperti laju pertumbuhan ekonomi, teknologi yang dipergunakan dan kebijaksanaan pemerintah. Dilihat dari sudut pandang makro, perluasan kesempatan kerja dapat terjadi melalui pertumbuhan ekonomi yaitu melalui proses kenaikan output per kapita secara konstan dalam jangka panjang (Boediono, 1999 : 1).

Dari sisi pengeluaran pemerintah yang berupa pengeluaran rutin dan pengeluaran pembangunan mendorong penerimaan masyarakat, melalui efek 
pelipatgandaan (Multiplier effect) (Boediono, 1999: 118), dimana peningkatan pendapatan tersebut mendorong konsumsi dan tabungan masyarakat serta peningkatan permintaan secara keseluruhan, sehingga memberi rangsangan bagi produsen untuk menambah investasi/memperluas kapasitas produksi akibatnya akan tercipta kesempatan kerja baru bagi masyarakat. Jadi pengeluaran pemerintah merupakan suatu cara untuk menggerakkan permintaan yang dapat memompa suatu perkonomian yang sedang tertekan dan memulihkan tingkat kesempatan yang tinggi (Heilbroner,1982: 216-217).

Berkaitan dengan itu maka permasalahan kesempatan kerja di Propinsi Nusa Tenggara Barat harus mendapat perhatian yang menyeluruh dan terpadu, karena salah satu esensi yang penting dalam pembangunan ekonomi adalah penyediaan lapangan kerja yang cukup untuk mengimbangi pertambahan angkatan kerja yang akan masuk ke pasar kerja. Pertumbuhan angkatan kerja selalu lebih cepat jika dibandingkan dengan pertumbuhan kesempatan kerja. Berdasarkan penjelasan latar belakang di atas, dapat disimpulkan bahwa terdapat keterkaitan yang sangat erat diantara variabel pengeluaran pemerintah, pertumbuhan ekonomi dan investasi terhadap penciptaan kesempatan kerja. Artinya, kesempatan kerja akan mengalami perubahan jika terjadi perubahan pada ketiga variabel di atas. Kebijakan penciptaan kesempatan kerja sudah sering menjadi prioritas pembangunan perekonomian bagi suatu negara ataupun daerah. Dengan demikian, perlu ada upaya dalam menggerakan sektor riil melalui investasi maupun pembelanjaan pemerintah, sehingga menaikkan pertumbuhan ekonomi yang pada akhirnya dapat memperluas kesempatan kerja. Semakin banyak tersedianya kesempatan kerja, dapat dipahami sebagai penurunan angka pengangguran dan terjadinya kenaikan dalam penciptaan output dan pendapatan masyarakat, yang bertendensi pada kenaikan permintaan, sehingga terjadi perkembangan dalam ekonomi.

Rumusan Masalah 
1) Bagaimanakah pengaruh Investasi, Pengeluaran Pemerintah dan Pertumbuhan ekonomi terhadap kesempatan kerja di propinsi Nusa tenggara Barat selama periode penelitian?

2) Bagaimanakah pengaruh Investasi, Pengeluaran Pemerintah dan Pertumbuhan ekonomi terhadap kesempatan kerja pada sektor pertanian, industri dan sektor jasa di Propinsi Nusa tenggara Barat selama periode penelitian?

3) Bagaimanakah pengaruh Investasi, Pengeluaran Pemerintah dan Pertumbuhan Ekonomi terhadap kesempatan kerja di setiap Daerah Kabupaten / Kota di Propinsi Nusa Tenggara Barat selama periode penelitian?

Tujuan

1) Untuk mengetahui pengaruh Investasi, Pengeluaran Pemerintah dan Pertumbuhan ekonomi terhadap kesempatan kerja di propinsi Nusa tenggara Barat selama periode penelitian.

2) Untuk mengetahui pengaruh Investasi, Pengeluaran Pemerintah dan Pertumbuhan ekonomi terhadap kesempatan kerja pada sektor pertanian, industri dan sektor jasa di Propinsi Nusa tenggara Barat selama periode penelitian.

3) Untuk mengetahui pengaruh Investasi, Pengeluaran Pemerintah dan Pertumbuhan Ekonomi terhadap kesempatan kerja di setiap Daerah Kabupaten / Kota di Propinsi Nusa Tenggara Barat selama periode penelitian.

\section{KAJIAN PUSTAKA}

\section{Landasan Teori}

\section{Kesempatan Kerja}

Kesempatan kerja adalah termasuk lapangan pekerjaan yang sudah diduduki (employment) dan masih lowong (vacancy). Dari lapangan pekerjaan yang masih lowong tersebut timbul kebutuhan tenaga kerja yang datang, misalnya dari perusahaan swasta maupun pemerintah atau departemen. 
Adanya kebutuhan tersebut berarti ada kesempatan kerja bagi orang yang menganggur untuk bekerja (Tambunan, 1998 : 325).

Berarti kesempatan kerja merupakan lapangan kerja yang ada dari suatu kegiatan ekonomi (produksi). Dengan kata lain kesempatan kerja menunjukkan banyaknya orang yang dapat tertampung untuk bekerja pada suatu perusahaan atau instansi. Sehingga perluasan kesempatan kerja sangat penting bukan saja untuk mengurangi pengangguran tetapi juga merupakan salah satu usaha untuk.peningkatan kemajuan perekonomian secara umum.

\section{Kesempatan Kerja Dan Investasi}

Investasi adalah kata kunci penentu laju pertumbuhan ekonomi, karena disamping akan mendorong kenaikan output secara signifikan, juga secara otomatis akan meningkatkan permintaan input, sehingga pada gilirannya akan meningkatkan kesempatan kerja dan kesejahteraan masyarakat sebagai konsekuensi dari meningkatnya pendapatan yang diterima masyarakat (Makmun \& Yasin, 2003 :63).

Rostow (dalam Todaro, 2000) menyatakan bahwa setiap upaya untuk tinggal landas mengharuskan adanya mobilisasi tabungan dalam dan luar negeri dengan maksud untuk menciptakan investasi yang cukup, untuk mempercepat pertumbuhan ekonomi sehingga pada gilirannya akan meningkatkan kesempatan kerja dan kesejahteraan masyarakat sebagai konsekuensi dari meningkatnya pendapatan yang diterima masyarakat.

\section{Kesempatan Kerja Dan Pengeluaran Pemerintah}

Pengeluaran Pemerintah merupakan bagian dari kebijakan fiskal, yaitu suatu tindakan pemerintah untuk mengatur jalannya perekonomian dengan cara menentukan besarnya penerimaan dan pengeluaran pemerintah setiap tahunnya (Reksoprayitno, 1997: 112). Dalam perspektif ekonomi, kebijakan fiskal memiliki berbagai tujuan dalam mengarahkan aktifitas ekonomi negara, yaitu peningkatan pertumbuhan ekonomi, stabilisasi negara, pemerataan distribusi pendapatan, dan peningkatan kesempatan kerja (Dornbusch and Fisher, 1994; Taggart, et.al, 2000). Dampak langsung aktifitas pemerintah terhadap perekonomian negara ditunjukkan oleh besar-kecilnya pengeluaran 
pemerintah, sehingga pengelolaan besaran pengeluaran pemerintah yang tidak tepat justru akan merugikan perekonomian.

Untuk itu jika pengeluaran pemerintah mampu menjadi pemandu peningkatan ekonomi Negara, maka peningkatan pada pengeluaran pemerintah akan meningkatkan aktifitas perekonomian dengan adanya peningkatan investasi. Peningkatan investasi tersebut akan memiliki dampak pula pada peningkatan output, kesempatan kerja, ekspor, pajak, penerimaan pemerintah, dan transaksi berjalan (Sriyana, 2006).

\section{Kesempatan Kerja Dan Pertumbuhan Ekonomi}

Salah satu indikator penting untuk menganalisis pembangunan ekonomi yang terjadi di suatu negara adalah pertumbuhan ekonomi, yang diukur dari perbedaan produk domestik bruto tahun tertentu dengan tahun sebelumnya (Setiawan \& Handoko, 2005: 1) Namun secara umum pertumbuhan ekonomi didefinisikan sebagai peningkatan kemampuan dari suatu perekonomian dalam memproduksi barang dan jasa. Dengan perkataan lain pertumbuhan ekonomi lebih menunjuk pada perubahan yang bersifat kuantitatif (quantitative change) dan biasanya diukur dengan menggunakan data Produk Domestik Regional Bruto (PDRB), atau Pendapatan atau Output Perkapita (lihat Jhingan, 2002: 57).

Dengan adanya penciptaan kesempatan kerja baru berarti adanya penciptaan pendapatan masyarakat yang akan mendorong daya beli masyarakat. Penciptaan kesempatan kerja baru juga dapat mendorong induced invesment, yang pada akhirnya akan mendorong pertumbuhan ekonomi daerah (Gravitiani, 2006: 39).

\section{Penelitian Terdahulu}

Penelitian terkait telah dilakukan oleh Chemingui dan Arsyad (2003) menyimpulkan bahwa terdapat korelasi yang kuat antara tenaga kerja dan pertumbuhan ekonomi di Algeria. Pertumbuhan ekonomi memungkinkan penggunaan stok modal manusia secara lebih baik melalui pengurangan tingkat pengangguran dan menaikkan tingkat upah rill. Pertumbuhan penciptaan kesempatan kerja secara berkelanjutan di Algeria mensyaratkan 
perubahan terus menerus dalam ekonomi politik domestik. Perluasan kesempatan kerja mensyaratkan juga perubahan dalam kebijakan dan peraturan pasar tenaga kerja.

Lebih lanjut penelitian yang dilakukan oleh Haynes \& Dinc (1997) menilai dasar-dasar kinerja perekonomian dan perubahan kesempatan kerja di 12 negara bagian di Amerika Serikat. Hasil penelitian menunjukkan bahwa perekonomian di negara bagian Sunbelt telah mengalami peningkatan dalam penyerapan tenaga kerja dan output, akan tetapi produktifitasnya tidak secepat di Negara bagian Snowbelt.

Berdasarkan penjelasan teoritis dan hasil penelitian terdahulu di atas, perluasan kesempatan kerja dapat terjadi melalui pertumbuhan ekonomi yaitu melalui proses kenaikan output perkapita dalam jangka panjang (Boediono, 1999). Peningkatan output cenderung didorong oleh investasi serta kebijakan fiskal yang ekspansif melalui peningkatan pengeluaran pemerintah. Dengan demikian akan mendorong naiknya perluasan kesempatan kerja. Artinya melalui investasi atau pengeluaran pemerintah, akan menaikkan penciptaan output, yang nantinya akan memperluas kesempatan kerja.

Dari uraian penjelasan tersebut, maka dalam penelitian ini akan di bangun suatu alur pemikiran dalam hubungannya diantara variabel investasi, pertumbuhan ekonomi dan pengeluaran pemerintah dengan kesempatan kerja. Adapun bagan dari alur pikir yang dilandasi oleh kajian teoritis maupun penelitian-penelitian empiris sebelumnya adalah sebagai berikut.

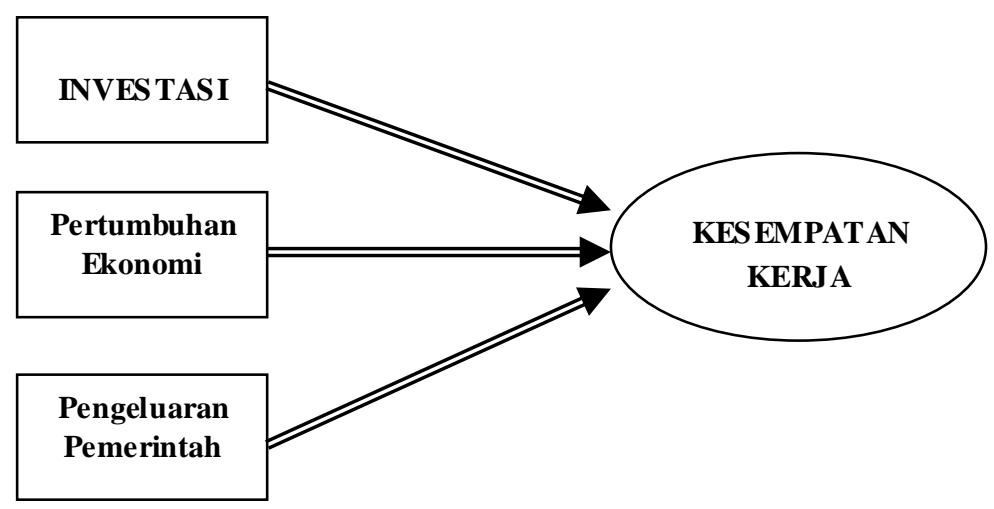




\section{Hipotesis}

Sejalan dengan deskripsi teoritis serta kerangka berpikir di atas, maka akan diuji suatu hipotesis penelitian berikut ini :

1. Bahwa Investasi, Pengeluaran Pemerintah dan Pertumbuhan Ekonomi berpengaruh signifikan terhadap Kesempatan Kerja di Propinsi NTB selama periode penelitian.

2. Bahwa Investasi, Pengeluaran Pemerintah dan Pertumbuhan Ekonomi berpengaruh signifikan terhadap Kesempatan Kerja pada sektor pertanian, industri dan sektor jasa di Propinsi NTB selama periode penelitian.

3. Bahwa Investasi, Pengeluaran Pemerintah dan Pertumbuhan Ekonomi berpengaruh signifikan terhadap Kesempatan Kerja di setiap daerah Kabupaten / Kota di Propinsi Nusa Tenggara Barat selama periode penelitian.

\section{Batasan dan Pengukuran Variabel}

Berdasarkan topik penelitian yang rumusannya mengandung beberapa variabel penting yang sekaligus merupakan variabel-variabel yang diteliti dalam penelitian ini, maka dapat di defenisioperasionalkan sebagai berikut :

1. Investasi adalah seluruh realisasi investasi yang dilakukan melalui PMA dan PMDN yang dinyatakan dalam satuan rupiah.

2. Pengeluaran Pemerintah adalah seluruh realisasi pengeluaran pemerintah (belanja rutin dan belanja pembangunan) setiap tahun dalam APBD Propinsi NTB yang dinyatakan dalam satuan rupiah.

3. Pertumbuhan ekonomi adalah banyaknya barang dan jasa yang mampu dihasilkan, yang diukur dari perkembangan PDRB, yang dinyatakan dalam satuan rupiah.

4. Kesempatan Kerja adalah jumlah penduduk yang bekerja, berdasarkan kesempatan kerja yang tersedia atau jumlah angkatan kerja yang mencari pekerjaan menurut BPS yang dinyatakan dalam satuan orang. 


\section{METODE PENELITIAN}

\section{Jenis dan Sumber Data}

Data yang digunakan dalam analisis meliputi data kuantitatif, dengan jenis data sekunder yang meliputi data tentang :

1. Investasi (PMA dan PMDN)

2. Pengeluaran Pemerintah (APBD)

3. Produk Domestik Regional Bruto (PDRB)

4. Kesempatan Kerja

Sedangkan Sumber data sekunder adalah instansi-instansi terkait, antara lain Bappeda, BKPMD, Tenaga Kerja dan Biro Pusat Statistik (BPS), serta laporan-laporan yang terkait dengan penelitian ini.

\section{Model Analisis}

Untuk menguji permasalahan pertama dan kedua yakni ingin mengetahui pengaruh Investasi, Pengeluaran Pemerintah dan Pertumbuhan Ekonomi terhadap Kesempatan Kerja, digunakan model persamaan regresi linier berganda sebagai berikut (Gujarati, 1995) :

$$
\mathrm{KK}=\beta \mathrm{o}+\beta_{1} \mathrm{I}+\beta_{2} \mathrm{GE}+\beta_{3} \mathrm{PE}+\varepsilon \mathrm{i}
$$

Di mana :

KK : Kesempatan Kerja

$$
\begin{array}{ll}
\beta_{0} & : \text { Konstanta / Intersep } \\
\text { I } & : \text { Investasi } \\
\text { GE } & : \text { Pengeluaran Pemerintah } \\
\text { PE } & : \text { Pertumbuhan Ekonomi } \\
\beta_{\mathrm{i}} & : \text { Merupakan Koefisien Regresi dari Independent Variabel. } \\
\varepsilon \mathrm{i} & : \text { Kesalahan Pengganggu (disturbance term) }
\end{array}
$$

Kemudian untuk membuktikan hipotesis ketiga, dimana ingin melihat pengaruh Investasi, Pengeluaran Pemerintah dan Pertumbuhan Ekonomi terhadap kesempatan kerja di setiap daerah Kabupaten/Kota di Propinsi NTB, maka digunakan model Panel Data dengan bentuk persamaan sebagai berikut (Nachrowi dan Usman, 2006) :

$$
Y_{i t}=\alpha+\beta X_{i t}+\varepsilon_{i t} \quad \mathbf{i}=\mathbf{1}, \mathbf{2}, \ldots, \mathbf{N} \text { dan } \mathbf{t}=\mathbf{1}, \mathbf{2}, \ldots, \mathbf{T}
$$


Di mana: $\mathrm{N}$ : Banyaknya observasi

$\mathrm{T}$ : Banyaknya waktu

NxT : Banyaknya data panel

$\mathrm{Y}_{i t}$ : Variabel terikat untuk individu ke-i dan waktu ke-t

$\mathrm{X}_{i t}$ : Variabel bebas untuk individu ke-i dan waktu ke-t

\section{HASIL PENELITIAN DAN PEMBAHASAN}

\section{Hasil Analisis Data}

Berdasarkan permasalahan dan hipotesis penelitian yang dikemukakan terkait kesempatan kerja, secara empiris hasilnya terbukti benar. Hal ini berarti bahwa penelitian ini dapat diterima sebagai suatu pengetahuan ilmiah, yang mana telah membuktikan kebenaran suatu teori secara empiris.

\section{Hasil Analisis Kesempatan Kerja di Prop. Nusa Tenggara Barat}

Berdasarkan pengujian secara parsial terlihat hanya variabel pengeluaran pemerintah yang tidak berpengaruh terhadap kesempatan kerja di Propinsi Nusa Tenggara Barat (Tabel 5.1.). Sementara variabel investasi dan pertumbuhan ekonomi (PDRB) berpengaruh positif terhadap kesempatan kerja di Propinsi Nusa Tenggara Barat. Pengaruh positif dari masing-masing variabel independen mengindikasikan bahwa terdapat hubungan yang searah diantara variabel investasi dan pertumbuhan ekonomi dengan kesempatan kerja. Dengan kata lain, jika terjadi kenaikan dalam investasi dan pertumbuhan ekonomi, maka akan menaikkan kesempatan kerja di Propinsi Nusa Tenggara Barat. Tidak signifikannya pengeluaran pemerintah disebabkan jenis pengeluaran lebih banyak difokuskan bukan pada pembelanjaan untuk keperluan pembangunan daerah, dan juga pembangunan daerah yang masih mengandalkan peranan dari sektor swasta. Selain itu juga berbagai kebijakan pemerintah yang tidak pada sasaran untuk pembangunan daerah.

Tabel 5.1. Pengujian Regresi Linier Kesempatan Kerja di Prop. NTB

\begin{tabular}{|l|c|c|c|c|}
\hline \multicolumn{1}{|c|}{ Variable } & Coefficient & Std. Error & t-Statistic & Probabilita \\
\hline Investasi & 0.000157 & $5.29 \mathrm{E}-05$ & $2.963638^{*}$ & 0.0080 \\
Pertumbuhan & 0.011528 & 0.004463 & $2.583332^{*}$ & 0.0182 \\
Peng. Pemerintah & $4.45 \mathrm{E}-06$ & $5.77 \mathrm{E}-06$ & 0.771178 & 0.4501 \\
Constant & -431.8312 & 264.2523 & -1.634163 & 0.1187 \\
\hline
\end{tabular}




\begin{tabular}{|l|l|l|l|}
\hline R-squared & 0.583117 & F-statistic * & $8.858789^{*}$ \\
Adjusted R-squared & 0.517294 & Prob(F-statistic) & 0.000700 \\
\hline
\end{tabular}

Keterangan :*) signifikan pada a $1 \%$ dan $5 \%$.

Dengan demikian, pemerintah daerah perlu lebih memfokuskan pada penyediaan maupun perbaikan di dalam berbagai sarana dan prasarana daerah yang dapat menarik masuknya investasi, yang nantinya dapat memperluas lapangan pekerjaan bagi tenaga kerja di daerah, yang sekaligus meningkatkan pertumbuhan ekonomi di Propinsi Nusa Tenggara Barat. Kebijakan fiskal melalui pengeluaran pemerintah agar perlu lebih di fokuskan pada permasalahan yang terkait langsung dengan penciptaan kesempatan kerja. Hal ini disebabkan dengan adanya penciptaan kesempatan kerja akan dapat meningkatkan pendapatan perkapita yang pada akhirnya menaikkan konsumsi maupun tabungan, sehingga berdampak pada kenaikan pertumbuhan output dan pertumbuhan ekonomi.

Besarnya proporsi atau variasi perubahan kesempatan kerja di Propinsi Nusa Tenggara Barat sebesar 51,73\% ditentukan oleh investasi, pertumbuhan ekonomi dan pengeluaran pemerintah. Sedangkan sisanya 48,72\% penciptaan kesempatan kerja ditentukan oleh variabel lain yang tidak dimasukan dalam model penelitian ini. Ini berarti masih terdapat banyak faktor lain yang turut mempengaruhi kesempatan kerja. Dengan demikian, diperlukan kebijakan pemerintah yang bisa menciptakan stabilisasi di berbagai aspek, sehingga memungkinkan penciptaan kesempatan kerja di Propinsi Nusa Tenggara Barat lebih mengandalkan faktor intern (tidak ada ketergantungan terhadap investasi asing).

\section{Hasil Analisis Kesempatan Kerja Sektor Pertanian di Propinsi NTB}

Di sektor pertanian setelah dilakukan pengujian secara parsial menunjukkan bahwa hanya variabel pertumbuhan ekonomi yang tidak berpengaruh signifikan. Sementara variabel investasi dan pengeluaran pemerintah berpengaruh terhadap kesempatan kerja di sektor pertanian di Propinsi Nusa Tenggara Barat (Tabel 5.2). Akan tetapi, pengeluaran pemerintah berpengaruh negatif terhadap kesempatan kerja. Pengaruh positif dari variabel 
investasi terhadap kesempatan kerja mengindikasikan bahwa jika terjadi kenaikan dalam investasi pada sektor pertanian, maka akan menaikkan kesempatan kerja di Propinsi Nusa Tenggara Barat. Pengaruh negatif pengeluaran pemerintah terhadap kesempatan kerja di sektor pertanian disebabkan pengeluaran yang diarahkan pada pembelian komoditi pertanian dari luar daerah (impor) sehingga menyebabkan merosotnya harga komoditi lokal. Selain itu juga, pengeluaran yang difokuskan pada pembangunan property dengan melakukan pembebasan lahan-lahan pertanian. Sementara, tidak signifikannya pertumbuhan ekonomi terhadap kesempatan kerja di sektor pertanian disebabkan kondisi sektor pertanian yang lebih bersifat tradisional yang hanya untuk kebutuhan konsumsi, dan lebih mengutamakan pada penggunaan tenaga kerja dari anggota keluarga sendiri. Besarnya proporsi atau perubahan kesempatan kerja pada sektor pertanian di Propinsi Nusa Tenggara Barat sebesar $81,11 \%$ ditentukan oleh investasi, pertumbuhan ekonomi dan pengeluaran pemerintah. Sedangkan sisanya 18,89\% penciptaan kesempatan kerja sektor pertanian ditentukan oleh variabel lain yang tidak dimasukan dalam model penelitian ini.

Tabel 5.2 Pengujian Regresi Linier Kesempatan Kerja Sektor Pertanian, Industri dan Jasa di Prop. Nusa Tenggara Barat

\begin{tabular}{|l|c|c|c|}
\hline Variable & $\begin{array}{c}\text { t-statistik } \\
\text { sektor } \\
\text { Pertanian }\end{array}$ & $\begin{array}{c}\text { t-statistik } \\
\text { sektor } \\
\text { Industri }\end{array}$ & $\begin{array}{c}\text { t-statistik } \\
\text { sektor Jasa }\end{array}$ \\
\hline Investasi & $5.547963^{*}$ & $2.894338^{*}$ & $5.145653^{*}$ \\
\hline Pertumbuhan & 1.444511 & $3.898494^{*}$ & $6.852769^{*}$ \\
\hline Ekonomi & & & \\
\hline Cong. Pemerintah & $-5.095568^{*}$ & $-4.284013^{*}$ & $4.485316^{*}$ \\
\hline R-squared & 1.570649 & 2.042820 & -2.737761 \\
\hline Adjusted R-squared & 0.836826 & 0.571540 & 0.746621 \\
\hline F-statistic & $32.47996^{*}$ & $8.448277^{*}$ & $18.66219^{*}$ \\
\hline
\end{tabular}

Keterangan $:^{*}$ ) signifikan pada a $1 \%$ dan $5 \%$. 
Melihat penjelasan di atas, maka dapat dipahami bahwa kurang efektifnya kebijakan pemerintah daerah setempat dalam menciptakan kesempatan kerja pada sektor pertanian di Propinsi Nusa Tenggara Barat. Hal ini disebabkan persentase dari total penduduk terbesar berada di pedesaan. Artinya, jika kebijakan pemerintah lebih mengarah pada pembangunan sektor pertanian, maka akan lebih banyak menyerap tenaga kerja yang menganggur, dibandingkan sektor industri yang bersifat pada modal (capital intensive), dan sekaligus terjadi pemerataan pendapatan antara masyarakat pedesaan dengan perkotaan.

\section{Hasil Analisis Kesempatan Kerja Sektor Industri di NTB}

Pengujian di sektor industri (Tabel 5.2) secara parsial menunjukkan bahwa variabel investasi dan pertumbuhan ekonomi (PDRB) berpengaruh positif terhadap kesempatan kerja di Propinsi Nusa Tenggara Barat. Pengaruh positif dari masing-masing variabel independen mengindikasikan bahwa terdapat hubungan yang searah diantara variabel investasi dan pertumbuhan ekonomi dengan kesempatan kerja. Dengan kata lain, jika terjadi kenaikan dalam investasi dan pertumbuhan ekonomi, maka akan menaikkan kesempatan kerja di Propinsi Nusa Tenggara Barat. Pengaruh positif dari variabel investasi dan pertumbuhan ekonomi terhadap kesempatan kerja mengindikasikan bahwa jika terjadi kenaikan dalam investasi pada sektor industri dan pertumbuhan ekonomi, maka akan menaikkan kesempatan kerja di Propinsi Nusa Tenggara Barat. Sementara pengaruh negatif dari pengeluaran pemerintah terhadap kesempatan kerja pada sektor indsutri disebabkan pengeluaran pemerintah yang tinggi akan menyebabkan tingginya jumlah uang beredar, yang akhirnya menaikkan suku bunga, sehingga menghambat investasi. Hal ini berdampak pada penciptaan kesempatan kerja. Selain itu juga, pengeluaran pemerintah yang dibiayai dengan menaikkan penerimaan pajak industri yang menyebabkan naiknya biaya produksi maupun biaya input lainnya, sehingga secara tidak langsung berdampak pada penurunan kesempatan kerja. Besarnya proporsi atau perubahan kesempatan kerja pada sektor pertanian di Propinsi Nusa Tenggara Barat sebesar 50,39\% ditentukan oleh investasi, pertumbuhan ekonomi dan pengeluaran pemerintah. Sedangkan sisanya 49,61\% penciptaan 
kesempatan kerja sektor industri ditentukan oleh variabel lain yang tidak dimasukan dalam model penelitian ini.

Perubahan dalam nilai investasi, pertumbuhan ekonomi dan pengeluaran pemerintah akan mempengaruhi penciptaan kesempatan kerja. Secara teoritis, tingginya investasi dan pertumbuhan ekonomi akan mengakibatkan tingginya permintaan tenaga kerja. Artinya, dengan adanya penanaman modal (investasi), maka sektor swasta akan memerlukan tenaga kerja sebagai input produksi untuk menjalankan kegiatan produksinya. Hal ini akan meningkatkan output perekonomian, sehingga meningkatkan pertumbuhan ekonomi. Sedangkan pengeluaran pemerintah dapat berpengaruh negatif maupun positif, tergantung pada formulasi kebijakan yang dijalankan. Jika kebijakan pengeluaran yang tidak diprioritaskan atau porsinya lebih kecil untuk pembangunan, maka bisa menurunkan penciptaan kesempatan kerja.

\section{Hasil Analisis Kesempatan Kerja Sektor Jasa di Propinsi NTB}

Hasil pengujian di sektor Jasa menunjukkan bahwa secara parsial variabel investasi, pertumbuhan ekonomi (PDRB) dan pengeluaran pemerintah berpengaruh positif terhadap kesempatan kerja di Propinsi Nusa Tenggara Barat (Tabel 5.2.). Pengaruh positif dari masing-masing variabel independen mengindikasikan bahwa terdapat hubungan yang searah diantara variabel investasi, pertumbuhan ekonomi, pengeluaran pemerintah dengan kesempatan kerja. Dengan kata lain, jika terjadi kenaikan dalam investasi, pertumbuhan ekonomi, dan pengeluaran pemerintah maka akan menaikkan kesempatan kerja pada sektor jasa di Propinsi Nusa Tenggara Barat. Besarnya proporsi atau variasi perubahan kesempatan kerja pada sektor pertanian di Propinsi Nusa Tenggara Barat sebesar 70,66\% ditentukan oleh investasi, pertumbuhan ekonomi dan pengeluaran pemerintah. Sedangkan sisanya 29,34\% penciptaan kesempatan kerja sektor jasa ditentukan oleh variabel lain yang tidak dimasukan dalam model penelitian ini.

Penjelasan di atas mengindikasikan bahwa sektor jasa merupakan sektor yang lebih produktif dibandingkan sektor lainnya. Artinya, sektor jasa lebih banyak menyediakan peluang kerja bagi angkatan kerja di Propinsi Nusa Tenggara Barat. Pengaruh positif dari investasi, pertumbuhan ekonomi dan 
pengeluaran pemerintah mencerminkan bahwa sektor jasa lebih menjadi andalan daerah dalam pembangunan ekonomi. Pengaruh positif dari pengeluaran pemerintah terhadap kesempatan kerja menunjukkan bahwa perhatian pemerintah terhadap pelayanan masyarakat sangat baik melalui pembangunan sektor jasa di daerah.

\section{Hasil Pengujian Kesempatan Kerja Per Kabupaten di Propinsi NTB}

Dalam menganalisis kesempatan kerja pada setiap daerah Kabupaten/Kota di Propinsi Nusa Tenggara Barat dilakukan panel data dengan menggunakan 2 (dua) pendekatan, yakni: Model Efek Tetap (MET) dan Model Efek Random (MER)

\section{Model Efek Tetap (Fixed Effect)}

Dasar pemikiran pembentukan Model Efek Tetap disebabkan adanya variabel-variabel yang tidak semuanya masuk dalam persamaan model memungkinkan adanya intercept yang tidak konstan. Atau dengan kata lain, intercept ini mungkin berubah untuk setiap individu dan waktu (Nachrowi \& Usman, 2006). Dalam pendekatan ini tidak memperhatikan dimensi individu maupun waktu. Diasumsikan bahwa perilaku data antar Kabupaten sama dalam berbagai kurun waktu.

Berdasarkan hasil pengujian dengan menggunakan Model Efek Tetap (Fixed Effect) hanya koefisien pertumbuhan ekonomi dan pengeluaran pemerintah yang signifikan secara statistik dengan uji t pada a 5\% dan $10 \%$ dan tandanya sesuai dengan yang diharapkan yaitu pertumbuhan ekonomi (PE) dan pengeluaran pemerintah (PP) berpengaruh positif terhadap kesempatan kerja (KK). Dengan menggunakan Model Fixed Effect ternyata nilai $\mathrm{R}^{2}$ yang didapat lebih tinggi dibandingkan dengan OLS, yaitu sebesar 82,85\%.

\section{Model Efek Random (Random Effect)}

Bila pada Model Efek Tetap, perbedaan antar individu dan atau waktu dicerminkan lewat intercept, maka pada Model Efek Random, perbedaan tersebut diakomodasi lewat error. Teknik ini juga memperhitungkan bahwa error mungkin berkorelasi sepanjang time series dan cross section. Mengingat ada dua komponen yang mempunyai kontribusi pada pembuatan error, yaitu individu dan waktu, maka random error pada Model Efek Random juga perlu 
diurai menjadi error untuk komponen individu, error komponen waktu dan error gabungan (Widarjono, 2005).

Berdasarkan hasil pengujian dengan menggunakan Model Random Effect hanya koefisien pertumbuhan ekonomi dan pengeluaran pemerintah yang signifikan secara statistik dengan uji t pada a $5 \%$ dan tandanya sesuai dengan yang diharapkan yaitu pertumbuhan ekonomi (PE) dan pengeluaran pemerintah berpengaruh positif terhadap kesempatan kerja (KK). Dengan menggunakan Model Random Effect ternyata nilai $\mathrm{R}^{2}$ yang didapat lebih tinggi dibandingkan dengan OLS, yaitu sebesar 79,12\%.

\section{Pembahasan Hasil Penelitian}

\section{Kesempatan Kerja dan Investasi di Propinsi NTB}

Dari hasil pengujian hipotesis yang dilakukan, menunjukkan bahwa penanaman modal (investasi) berpangaruh positif terhadap kesempatan kerja. Dengan adanya penanaman modal (investasi) tentunya akan mendorong terciptanya kesempatan kerja yang pada gilirannya menaikkan output perekonomian. Pengaruh investasi terhadap kesempatan kerja telah sesuai dengan teori yang dikemukakan oleh Rostow (dalam Todaro, 2000) yang menyatakan bahwa setiap upaya untuk tinggal landas mengharuskan adanya mobilisasi tabungan dalam dan luar negeri dengan maksud untuk menciptakan investasi yang cukup, untuk mempercepat pertumbuhan ekonomi sehingga pada gilirannya akan meningkatkan kesempatan kerja dan kesejahteraan masyarakat sebagai konsekuensi dari meningkatnya pendapatan yang diterima masyarakat. Investasi harus dipandang sebagai motor penggerak utama pertumbuhan ekonomi, menciptakan kesempatan kerja dan meningkatkan daya saing internasional bukan hanya sekedar menutupi kekurangan pembiayaan (Sinar Harapan, 2003). Sehingga Investasi diharapkan sebagai mobilisasi sumber daya untuk menciptakan atau menambah kapasitas produksi atau pendapatan di masa yang akan datang. Parkin dan Bade (1992) melihat besarnya permintaan tenaga kerja dapat ditunjukkan oleh jumlah orang yang bekerja pada suatu saat. Dengan demikian, jumlah orang yang bekerja merupakan kesempatan kerja. Kesempatan kerja berubah dari waktu ke waktu 
namun sebenarnya penyebab perubahannya terletak pada bidang ekonomi. Perubahan yang terlihat pada situasi ekonomi membawa dampak pada kesempatan kerja. Dengan kata lain besarnya kesempatan kerja peka terhadap perubahan ekonomi.

\section{Kesempatan Kerja dan Pertumbuhan Ekonomi di Propinsi NTB}

Dalam pengujian hipotesis yang telah dilakukan diperoleh hasil bahwa pertumbuhan ekonomi berpengaruh positif terhadap kesempatan kerja. Pertumbuhan ekonomi yang tinggi, yang disebabkan oleh kenaikan dalam pertambahan output, akan berdampak pada penciptaan kesempatan kerja, yang nantinya berpotensi pada kenaikan dalam pendapatan perkapita. Menurut Todaro (2000), bahwa model pertumbuhan dan kesempatan kerja menghubungkan tingkat penyediaan kesempatan kerja dengan tingkat pertumbuhan GNP. Todaro mengisyaratkan bahwa dengan memaksimumkan pertumbuhan GNPnya negara-negara dunia ketiga dapat pula memaksimumkan penyerapan tenaga kerja. Hal ini sejalan dengan penelitian yang dilakukan oleh Haynes \& Dinc (1997) dengan menilai dasar-dasar kinerja perekonomian dan perubahan kesempatan kerja di 12 negara bagian di Amerika Serikat. Hasil penelitian menunjukkan bahwa perekonomian di negara bagian Sunbelt telah mengalami peningkatan dalam penyerapan tenaga kerja dan output, akan tetapi produktifitasnya tidak secepat di Negara bagian Snowbelt.

\section{Kesempatan Kerja dan Pengeluaran Pemerintah di Propinsi NTB}

Dampak langsung aktifitas pemerintah terhadap perekonomian negara ditujukan oleh besar-kecilnya pengeluaran pemerintah. Sehingga pengelolaan besaran pengeluaran pemerintah yang tidak tepat justru akan merugikan perekonomian. Jika pengeluaran pemerintah mampu menjadi pemandu peningkatan ekonomi Negara, maka peningkatan pada pengeluaran pemerintah akan meningkatkan aktifitas perekonomian dengan adanya peningkatan investasi. Peningkatan investasi tersebut akan memiliki dampak pula pada peningkatan output, kesempatan kerja, ekspor, pajak, penerimaan pemerintah, dan transaksi berjalan (Sriyana, 2006). 
Berdasarkan pengujian hipotesis yang dilakukan ternyata variabel pengeluaran pemerintah tidak mempengaruhi penciptaan kesempatan kerja di Propinsi Nusa Tenggara Barat. Tidak signifikannya pengeluaran pemerintah menunjukkan bahwa penciptaan kesempatan kerja di Propinsi Nusa Tenggara Barat bukan disebabkan oleh kebijakan dari pemerintah daerah setempat, akan tetapi masih bertumpu pada berkembangnya usaha-usaha dari sektor swasta. Hal ini juga mengindikasikan bahwa jika adanya kenaikan pembelanjaan pemerintah dengan menaikkan penerimaan dari sektor pajak, maka akan berdampak pada penurunan kesempatan kerja. Sejalan dengan penjelasan tersebut, Mankiw (2003) menjelaskan bahwa dengan adanya kenaikan pemerintah (ekspansi fiskal) maka akan menghambat investasi, yang pada gilirannya menurunkan kesempatan kerja dan pertumbuhan ekonomi.

\section{Kesempatan Kerja dan Investasi Pada Sektor Ekonomi}

Berdasarkan hasil pengujian hipotesis, menunjukkan bahwa penanaman modal (investasi) berpangaruh positif terhadap kesempatan kerja di sektor pertanian, industri, dan sektor jasa. Dengan adanya penanaman modal (investasi) tentunya akan mendorong terciptanya kesempatan kerja yang pada gilirannya menaikkan output perekonomian. Pengaruh investasi terhadap kesempatan kerja telah sesuai dengan teori yang dikemukakan oleh Rostow (dalam Todaro, 2000) yang menyatakan bahwa setiap upaya untuk tinggal landas mengharuskan adanya mobilisasi tabungan dalam dan luar negeri dengan maksud untuk menciptakan investasi yang cukup, untuk mempercepat pertumbuhan ekonomi sehingga pada gilirannya akan meningkatkan kesempatan kerja dan kesejahteraan masyarakat sebagai konsekuensi dari meningkatnya pendapatan yang diterima masyarakat. Investasi harus dipandang sebagai motor penggerak utama pertumbuhan ekonomi, menciptakan kesempatan kerja dan meningkatkan daya saing internasional bukan hanya sekedar menutupi kekurangan pembiayaan (Sinar Harapan, 2003). Sehingga Investasi diharapkan sebagai mobilisasi sumber daya untuk menciptakan atau menambah kapasitas produksi atau pendapatan di masa yang akan datang. Parkin dan Bade (1992) melihat besarnya permintaan tenaga kerja dapat ditunjukkan oleh jumlah orang yang bekerja pada suatu saat. 
Dengan demikian, jumlah orang yang bekerja merupakan kesempatan kerja. Kesempatan kerja berubah dari waktu ke waktu namun sebenarnya penyebab perubahannya terletak pada bidang ekonomi. Perubahan yang terlihat pada situasi ekonomi membawa dampak pada kesempatan kerja. Dengan kata lain besarnya kesempatan kerja peka terhadap perubahan ekonomi.

\section{Kesempatan Kerja dan Pertumbuhan Ekonomi Pada Sektor Ekonomi}

Dalam pengujian hipotesis yang telah dilakukan diperoleh hasil bahwa pertumbuhan ekonomi berpengaruh positif terhadap kesempatan kerja hanya pada sektor industri dan sektor jasa. Sementara pertumbuhan ekonomi tidak berpengaruh pada kesempatan kerja di sektor pertanian. Hal ini dapat dipahami bahwa tenaga kerja pada sektor pertanian sebagian besar berasal dari anggota keluarga sendiri dan disebabkan kondisi luas lahan cenderung tetap, sehingga penciptaan kesempatan kerja pada sektor pertanian di daerah penelitian tidak dapat diciptakan. Menurut Todaro (2000), bahwa model pertumbuhan dan kesempatan kerja menghubungkan tingkat penyediaan kesempatan kerja dengan tingkat pertumbuhan GNP. Akan tetapi, kondisi tersebut akan berbeda pada sektor pertanian, yang mana sering berlaku law of diminshing returns. Artinya bahwa terdapat hubungan terbalik antara pertambahan tenaga kerja dengan pertambahan output, sehingga dengan pertambahan tenaga kerja secara terus-menerus akan menurunkan pertambahan output.

\section{Kesempatan Kerja dan Pengeluaran Pemerintah Pada Sektor Ekonomi}

Dampak langsung aktifitas pemerintah terhadap perekonomian negara ditujukan oleh besar-kecilnya pengeluaran pemerintah. Sehingga pengelolaan besaran pengeluaran pemerintah yang tidak tepat justru akan merugikan perekonomian. Jika pengeluaran pemerintah mampu menjadi pemandu peningkatan ekonomi negara, maka peningkatan pada pengeluaran pemerintah akan meningkatkan aktifitas perekonomian dengan adanya peningkatan investasi. Peningkatan investasi tersebut akan memiliki dampak pula pada peningkatan output, kesempatan kerja, ekspor, pajak, penerimaan pemerintah, dan transaksi berjalan (Sriyana, 2006). 
Berdasarkan hasil pengujian hipotesis yang dilakukan ternyata variabel pengeluaran pemerintah mempengaruhi penciptaan kesempatan kerja pada sektor pertanian, industri maupun sektor jasa di Propinsi Nusa Tenggara Barat. Akan tetapi terdapat pengaruh negatif dari pengeluaran pemerintah terhadap penciptaan kesempatan kerja pada sektor pertanian dan sektor industri. Hal ini mengindikasikan bahwa jika adanya kenaikan pembelanjaan pemerintah dengan menaikkan penerimaan dari sektor pajak, maka akan berdampak pada penurunan kesempatan kerja pada sektor industri, dan adanya pengurangan dalam pengeluaran pemerintah terhadap pembelian komoditi pertanian dari luar daerah yang menyebabkan harga produk lokal naik, sehingga terjadi kenaikan dalam kesempatan kerja.

\section{Kesempatan Kerja dan Investasi Per Kabupaten/Kota di NTB}

Investasi harus dipandang sebagai motor penggerak utama pertumbuhan ekonomi, menciptakan kesempatan kerja dan meningkatkan daya saing internasional bukan hanya sekedar menutupi kekurangan pembiayaan (Sinar Harapan, 2003). Sehingga Investasi diharapkan sebagai mobilisasi sumber daya untuk menciptakan atau menambah kapasitas produksi atau pendapatan di masa yang akan datang. Parkin dan Bade (1992) melihat besarnya permintaan tenaga kerja dapat ditunjukkan oleh jumlah orang yang bekerja pada suatu saat. Dengan demikian, jumlah orang yang bekerja merupakan kesempatan kerja. Kesempatan kerja berubah dari waktu ke waktu namun sebenarnya penyebab perubahannya terletak pada bidang ekonomi. Perubahan yang terlihat pada situasi ekonomi membawa dampak pada kesempatan kerja. Dengan kata lain besarnya kesempatan kerja peka terhadap perubahan ekonomi.

Hal tersebut dibuktikan dari hasil pengujian hipotesis, yang menunjukkan bahwa penanaman modal (investasi) di semua daerah Kabupaten / Kota di

Propinsi Nusa Tenggara Barat tidak berpengaruh terhadap penciptaan kesempatan kerja. Tidak siginifikannya investasi ini disebabkan terjadi crowding out akibat kenaikan dalam pembelanjaan pemerintah yang menyebabkan naiknya suku bunga, sehingga menurunkan rencana investasi dari para pengusaha pada berbagai daerah di Propinsi Nusa Tenggara Barat. 


\section{Kesempatan Kerja dan Pert. Ekonomi Per Kabupaten/Kota di NTB}

Dalam pengujian hipotesis yang telah dilakukan diperoleh hasil bahwa pertumbuhan ekonomi berpengaruh positif terhadap kesempatan kerja pada setiap Kabupaten / Kota di Propinsi Nusa Tenggara Barat. Pertumbuhan ekonomi yang tinggi, yang disebabkan oleh kenaikan dalam pertambahan output, akan berdampak pada penciptaan kesempatan kerja, yang nantinya berpotensi pada kenaikan dalam pendapatan perkapita. Menurut Todaro (2000), bahwa model pertumbuhan dan kesempatan kerja menghubungkan tingkat penyediaan kesempatan kerja dengan tingkat pertumbuhan GNP. Hal ini sejalan dengan penelitian yang dilakukan oleh Haynes \& Dinc (1997) dengan menilai dasar-dasar kinerja perekonomian dan perubahan kesempatan kerja di 12 negara bagian di Amerika Serikat. Hasil penelitian menunjukkan bahwa perekonomian di negara bagian Sunbelt telah mengalami peningkatan dalam penyerapan tenaga kerja dan output, akan tetapi produktifitasnya tidak secepat di Negara bagian Snowbelt.

Dari penjelasan di atas, maka dapat dipahami bahwa analisis tentang laju pertumbuhan ekonomi selalu digunakan untuk mengetahui sektor mana yang menguntungkan dan berpotensi dimasa yang akan datang, yang pada akhirnya akan dapat memperbesar peluang investasi bagi Kabupaten atau kota untuk menarik investasi ke daerah, sehingga akan dapat menimbulkan multiplier effect bagi daerah berupa penciptaan lapangan kerja atau kesempatan kerja baru. Dengan adanya penciptaan kesempatan kerja baru berarti adanya penciptaan pendapatan masyarakat yang akan mendorong daya beli masyarakat (Gravitiani, 2006).

\section{Kesempatan Kerja dan Pengeluaran Pemerintah Per Kab./Kota di NTB}

Dampak langsung aktifitas pemerintah terhadap perekonomian negara ditujukan oleh besar-kecilnya pengeluaran pemerintah. Sehingga pengelolaan besaran pengeluaran pemerintah yang tidak tepat justru akan merugikan perekonomian. Jika pengeluaran pemerintah mampu menjadi pemandu peningkatan ekonomi Negara, maka peningkatan pada pengeluaran pemerintah akan meningkatkan aktifitas perekonomian dengan adanya peningkatan investasi. Peningkatan investasi tersebut akan memiliki dampak 
pula pada peningkatan output, kesempatan kerja, ekspor, pajak, penerimaan pemerintah, dan transaksi berjalan (Sriyana, 2006).

Terbukti dengan hasil pengujian hipotesis yang dilakukan ternyata variabel pengeluaran pemerintah berpengaruh positif terhadap penciptaan kesempatan kerja pada semua daerah Kabupaten / Kota di Propinsi Nusa Tenggara Barat. Hal ini berarti bahwa jika pemerintah menaikkan pembelanjaannya (ekspansi fiskal) maka akan berdampak pada kenaikan dalam kesempatan kerja pada setiap daerah di Propinsi Nusa Tenggara Barat. Keseluruhan pengeluaran pemerintah merupakan penerimaan masyarakat. Sama halnya dengan masyarakat, pengeluaran pemerintah akan memperbesar permintaan agregat dan melalui peningkatan permintaan agregat, produksi atau penawaran agregat akan meningkat sehingga kesempatan kerja dapat diketahui melalui besarnya angka pengganda pengeluaran pemerintah (Boediono, 1998).

\section{Implikasi Hasil Penelitian}

Chemingui dan Arsyad (2003) menyimpulkan bahwa terdapat korelasi yang kuat antara tenaga kerja dan pertumbuhan ekonomi di Algeria. Pertumbuhan ekonomi memungkinkan penggunaan stok modal manusia secara lebih baik melalui pengurangan tingkat pengangguran dan menaikkan tingkat upah rill. Pertumbuhan penciptaan kesempatan kerja secara berkelanjutan di Algeria mensyaratkan perubahan terus menerus dalam ekonomi politik domestik. Perluasan kesempatan kerja mensyaratkan juga perubahan dalam kebijakan dan peraturan pasar tenaga kerja.

Berdasarkan hasil penelitian ini ternyata terdapat kesamaan bahwa pertumbuhan ekonomi berpengaruh positif terhadap perluasan kesempatan kerja di Propinsi Nusa Tenggara Barat. Akan tetapi, penciptaan kesempatan kerja sektor pertanian yang tidak dipengaruhi oleh pertumbuhan ekonomi daerah.

Hasil penelitian Haynes \& Dinc (1997) di 12 negara bagian di Amerika Serikat menunjukkan bahwa perekonomian di negara bagian Snowbelt telah mengalami peningkatan dalam penyerapan tenaga kerja dan output, akan tetapi produktifitasnya tidak secepat di negara bagian Snowbelt. Sedangkan 
Fertig (2003) melakukan penelitian mengenai dampak integrasi ekonomi Uni Eropa terhadap kesempatan kerja tahun 1980-2000 terungkap bahwa indeks integrasi untuk negara anggota bagian selatan, tingkat pertumbuhan investasi, GDP per kapita dan trend waktu berpengaruh positif terhadap kesempatan kerja, sedangkan variabel yang lain berpengaruh negatif. Penyatuan Uni Eropa menyebabkan adanya tambahan kesempatan kerja serta peningkatan hasil (outcome).

Hasil penelitian ini menunjukkan hasil yang sama, dimana terdapat pengaruh pertumbuhan ekonomi dan pertumbuhan investasi terhadap kesempatan kerja di Propinsi NTB, dan juga pada sektor ekonomi (pertanian, industri dan jasa). Namun, pada setiap daerah Kabupaten/Kota, pertumbuhan investasi tidak berpengaruh terhadap penciptaan kesempatan kerja. Hal ini mengindikasikan bahwa di daerah-daerah Kabupaten/Kota perlu dilakukan perbaikan iklim investasi, disebabkan dengan tingginya pertumbuhan investasi maka akan mendorong pertumbuhan output yang nantinya menaikkan kesempatan kerja bagi masyarakat daerah setempat.

Lebih lanjut penelitian yang dilakukan oleh Wahyuni (2004) meneliti tentang peran pemerintah dalam pertumbuhan ekonomi di 20 negara Asia Pasifik yang mempunyai kesamaan latar belakang ekonomi periode 1980 2000. Studi tersebut memberikan hasil bahwa koefisien pangsa pengeluaran pemerintah terhadap GDP adalah negatif. Hubungan negatif ini menunjukkan bahwa komponen konsumsi mendominasi pengeluaran anggaran pemerintah. Hasil ini sejalan dengan kenyataan bahwa sebagian besar negara-negara dikawasan itu menemui masalah dalam manajemen pengeluaran pemerintah. Jadi pengeluaran yang besar untuk konsumsi bagi kepentingan pemerintah sendiri menutupi efek positif investasi publik.

Perbedaan dalam penelitian ini dengan penelitian sebelumnya antara lain bahwa penelitian ini menganalisis kesempatan kerja pada setiap sektor ekonomi (pertanian, industri dan jasa) dan pada setiap daerah Kabupaten/Kota dengan melakukan panel data. Selain itu juga, hasil yang ditemukan menunjukkan perbedaan bahwa kesempatan kerja pada sektor pertanian tidak dipengaruhi oleh pertumbuhan ekonomi. Sementara pada setiap daerah 
Kabupaten/Kota menunjukkan bahwa pertumbuhan investasi tidak mempengaruhi penciptaan kesempatan kerja di daerah.

\section{Kesimpulan}

1. Berdasarkan hasil analisis data dalam penelitian ini menunjukkan bahwa pertumbuhan ekonomi dan penanaman modal (investasi) berpengaruh positif terhadap penciptaan kesempatan kerja di Propinsi Nusa Tenggara Barat. Sementara kebijakan fiskal melalui pengeluaran pemerintah tidak berpengaruh, yang disebabkan masih terfokusnya sebagian besar alokasi dana dalam APBD kepada persoalan internal pemerintah daerah setempat (seperti belanja pegawai, belanja barang, belanja rutin daerah, bunga dan cicilan utang dan pengeluaran rutin lainnya).

2. Berdasarkan hasil analisis data dalam penelitian ini menunjukkan bahwa kesempatan kerja pada sektor pertanian di Propinsi Nusa Tenggara Barat cenderung dipengaruhi oleh investasi dan pertumbuhan ekonomi. Akan tetapi, untuk pengeluaran pemerintah pengaruhnya negatif. Hal ini disebabkan kebijakan pengeluaran pemerintah yang tidak memperhitungkan efeknya terhadap masyarakat (khususnya petani), sehingga berdampak negatif. Namun, kebijakan yang dijalankan hendaknya mengarah pada peningkatan produktivitas di sektor pertanian.

3. Hasil analisis data menunjukkan bahwa investasi dan pertumbuhan ekonomi berpengaruh positif terhadap kesempatan kerja di sektor industri. Sementara pengeluaran pemerintah berpengaruh negatif, yang disebabkan pemerintah dalam membiayai konsumsinya lebih diutamakan pada menaikkan penerimaan dari pajak. Hal ini menyebabkan para pengusaha mengurungkan niatnya untuk rencana investasi, sehingga akan menurunkan output dan kesempatan kerja.

4. Berdasarkan hasil analisis data dalam penelitian ini menunjukkan bahwa investasi, pertumbuhan ekonomi dan pengeluaran pemerintah berpengaruh positif terhadap kesempatan kerja di sektor jasa di Propinsi Nusa Tenggara Barat. Artinya bahwa jika terjadi kenaikan dalam investasi, pertumbuhan ekonomi maupun pengeluaran pemerintah maka akan menaikkan 
kesempatan kerja.

5. Penciptaan kesempatan kerja di setiap daerah Kabupaten / Kota di Propinsi Nusa Tenggara Barat lebih dipengaruhi oleh perubahan atau naik turunnya tingkat pertumbuhan ekonomi dan pengeluaran pemerintah. Terdapat hubungan positif diantara kesempatan kerja dengan pertumbuhan ekonomi dan pengeluaran pemerintah. Artinya, jika terjadi kenaikan dalam pertumbuhan ekonomi atau pengeluaran pemerintah pada setiap daerah, maka akan menaikkan tingkat kesempatan kerja.

\section{Saran}

1. Mengingat penanaman modal (investasi) dan pertumbuhan ekonomi merupakan variabel yang berpengaruh positif terhadap kesempatan kerja di Propinsi Nusa Tenggara Barat, maka pemerintah daerah perlu lebih profesional dalam merumuskan suatu kebijakan yang dapat berdampak pada penciptaan kesempatan kerja yang lebih baik di masa yang akan datang, sehingga secara tidak langsung terjadi peningkatan dalam pendapatan perkapita dari masyarakat. Selain itu juga kebijakan pemerintah agar tidak menghambat investasi, sehingga para pengusaha akan lebih terdorong untuk melakukan ekspansi dalam usahanya, yang bertendensi pada penciptaan kesempatan kerja.

2. Dengan diketahui bahwa Investasi dan pertumbuhan ekonomi berpengaruh terhadap kesempatan kerja di sektor pertanian, maka perlu adanya suatu kebijakan dari pemerintah yang dapat lebih meningkatkan produktivitas masyarakat petani, sehingga para petani bukan hanya dapat meningkatkan output dari segi kuantitas melainkan juga dari segi kualitas. Disebabkan pengaruh pengeluaran pemerintah yang negatif terhadap kesempatan kerja di sektor pertanian, maka pemerintah daerah setempat perlu merevisi alokasi pengeluaran ke jenis pengeluaran yang lebih produktif.

3. Dalam penelitian ini, investasi dan pertumbuhan ekonomi berpengaruh positif terhadap kesempatan kerja di sektor industri, sedangkan pengeluaran pemerintah berpengaruh negatif. Untuk itu pemerintah perlu lebih berhati-hati dalam menjalankan kebijakannya agar tidak merugikan 
sektor swasta, sehingga tidak berdampak pada penciptaan kesempatan kerja di sektor industri.

4. Berdasarkan analisis yang dilakukan, ternyata investasi, pertumbuhan ekonomi dan pengeluaran pemerintah berpengaruh positif terhadap kesempatan kerja di sektor jasa. Dengan demikian, pemerintah daerah perlu memikirkan formulasi kebijakan yang lebih strategis, yang nantinya berdampak pada penciptaan kesempatan kerja di sektor jasa dalam kurun waktu yang lebih panjang (kebijakan stabilisasi).

\section{DAFTAR PUSTAKA}

Arestis, Philip., Mosahid Khan, dan Kul B. Luintel, 2002, Fiscal Deficits in Monetary Unions: A Comparasion of EMU and United States, Eastern Economic Journal, Vol.1, No. 1, Winter : 89 - 104

Boediono, 1999, Teori Pertumbuhan Ekonomi, Seri Sinopsis, Pengantar Ilmu Ekonomi No. 4, Edisi Pertama, Cetakan Keenam, BPFE, Yogyakarta.

Chemingui, Mohamed Adelbasset, dan Nasima Ayadi, 2003, Labor Market and Economic Growth in Algeria, http://www.google.com.

Dornbusch, Rudiger dan Stanley Fischer, 1987, Makro Ekonomi, Alih Bahasa J. Mulyadi, Edisi Keempat, Penerbit Erlangga, Jakarta.

Fertig, Michael, 2003, The Impact of Economic Integration on Employment - An Assessment in The Context of EU Enlargement, IZA Discussions Papers No. 919, http:/ / www.IZA.org.

Gujarati, Damodar N, 1995, Basic Econometrics, Four Edition, Mc Graw-Hill Higher Education, New York.

Gravitiani, Evi, 2006, Analisis Shift-Share Dinamik pada Perekonomian Kota Yogyakarta, Jurnal Ekonomi dan Studi Pembangunan, Vol. 7, No.1 April, hal 35 - 48.

Haynes, Kingsley and Dinc Mustafa, 1997, Productivity in Manufacturing Regions : A Multifactor/Shife-Share Approach, Growth and Change, Volume 28, 201 - 221. www.Google.com.

Heilbroner, Robert L, 1982, Terbentuknya Masyarakat Ekonomi, Edisi keenam (terjemahan), Ghalia Indonesia, Jakarta.

Jhingan, M.L., 2002, Ekonomi pembangunan dan Perencanaan, diterjemahkan oleh D.Guritno, Edisi Kesembilan, PT. Raja Grafindo Persada, Jakarta

Kidd, Michael P, dan Ferko, Ivan, 2001, The Employment Effects of Gender Discrimination in Australia 1994 - 1995, Journal Economic Record, Vol. 77, No. 236, 71 - 88. 
Makmun, Akhmad Yasin, 2003, Pengaruh Investasi dan Tenaga Kerja Terhadap PDB sektor Pertanian, Kajian Ekonomi dan Keuangan, Vol.7, No.3 : 63.

Mankiw, Gregory. N., 2002., Macroeconomics $5^{\text {th }}$ Edition. New York and Basingstoke, by Worth Publishers. Terjemahan, Penerbit Erlangga.

Nachrowi, Usman Hardius, 2006, Pendekatan Populer dan Praktis Ekonometrika Untuk Analisis Ekonomi dan Keuangan, Penerbit FE-UI.

Parkin, Michael dan Robin Bade, 1992, Modern Macroeconomics, Edisi Kedua, Mc Graw Hill Book Co, New York, USA.

Reksoprayitno, Soediyono, 2000, Pengantar Ekonomi Makro, Edisi enam, Penerbit BPFE Yogyakarta.

Setiawan, Sigit \& Rudi Handoko, 2005, Pertumbuhan Ekonomi 2006 : Suatu Estimasi dan Arah Pencapaian Pertumbuhan Yang Merata dan Berkualitas, Kajian Ekonomi dan Keuangan, Vol. 9, No. 4, hal. 1.

Taggart, Douglass Mc, Christoper Findlay, 1999, Michael Parkin, 1999, Macroeconomics, Addison-Wesley.

Tambunan, Tulus, 1994, Mengukur besarnya Peranan Industri Kecil dan Rumah Tangga di dalam perekonomian Regional:Beberapa Indikator, Agro-Ekonomika, No.1 Thn XXIV, $10-11$.

Todaro, Michael P, 2000, Ekonomi pembangunan di Dunia Ketiga, Edisi Ketujuh, Penerbit Erlangga, Jakarta.

Wahyuni, Heni, 2004, The Role of Government in Economic Growth : Evidence From Asia and Pasific Countries, Jurnal Ekonomi dan Bisnis Indonesia, Vol. 19, No. $1: 71-81$.

Widarjono, Agus. 2005., Ekonometrika: Teori dan Aplikasi untuk Ekonomi dan Bisnis, Edisi Pertama. Penerbit Ekonisia Fakultas Ekonomi UII, Yogyakarta.

\section{*) Muammil Sun'an, Dosen Universitas Sultan Khairun Ternate \\ **) Endang Astuti , Dosen Universitas Negeri Mataram}


Hasil Panel Data Kesempatan Kerja di Propinsi Nusa Tenggara Barat

Model Efek Tetap (Fixed Effect)

\begin{tabular}{|c|c|c|c|c|}
\hline \multicolumn{5}{|c|}{ Dependent Variable: KK? } \\
\hline \multicolumn{5}{|c|}{ Method: Pooled Least Squares } \\
\hline \multicolumn{5}{|c|}{ Date: 04/06/07 Time: 21:07 } \\
\hline \multicolumn{5}{|l|}{ Sample: 20012005} \\
\hline \multicolumn{5}{|c|}{ Included observations: 5} \\
\hline \multicolumn{5}{|c|}{ Cross-sections included: 7} \\
\hline \multicolumn{5}{|c|}{ Total pool (balanced) observations: 35} \\
\hline Variable & Coefficient & Std. Error & t-Statistic & Prob. \\
\hline $\mathrm{C}$ & 1986.392 & 2.463828 & 806.2220 & 0.0000 \\
\hline INV? & -0.006940 & 0.008625 & -0.804676 & 0.4286 \\
\hline PE? & 9.89E-09 & $5.25 \mathrm{E}-09$ & 1.884498 & 0.0712 \\
\hline PP? & $1.23 \mathrm{E}-05$ & $1.61 \mathrm{E}-06$ & 7.614903 & 0.0000 \\
\hline \multicolumn{5}{|c|}{ Fixed Effects (Cross) } \\
\hline _LOBAR - C & -6.004398 & & & \\
\hline _LOTENG - C & -2.161412 & & & \\
\hline _LOTIM-C & -6.604343 & & & \\
\hline _SUMBAWA - C & 0.804739 & & & \\
\hline _DOMPU-C & 8.458383 & & & \\
\hline _BIMA - C & 3.661138 & & & \\
\hline _MATARAM-C & 1.845892 & & & \\
\hline
\end{tabular}




\begin{tabular}{|lrll|}
\hline \multicolumn{4}{|c|}{ Effects Specification } \\
\hline Cross-section fixed (dummy variables) & \\
R-squared & 0.828470 & Mean dependent var & 2003.000 \\
Adjusted R-squared & 0.766720 & S.D. dependent var & 1.434860 \\
S.E. of regression & 0.693025 & Akaike info criterion & 2.339454 \\
Sum squared resid & 12.00708 & Schwarz criterion & 2.783839 \\
Log likelihood & -30.94045 & F-statistic & 13.41637 \\
Durbin-Watson stat & 1.151196 & Prob(F-statistic) & 0.000000 \\
\hline
\end{tabular}

Model Efek Random (Random Effect)

Dependent Variable: KK?

Method: Pooled EGLS (Cross-section random effects)

Date: 04/06/07 Time: 21:09

Sample: 20012005

Included observations: 5 
Cross-sections included: 7

Total pool (balanced) observations: 35

\begin{tabular}{|c|c|c|c|c|}
\hline Variable & Coefficient & Std. Error & t-Statistic & Prob. \\
\hline $\mathrm{C}$ & 1988.670 & 4.980377 & 399.3011 & 0.0000 \\
\hline INV? & -0.012690 & 0.007855 & -1.615547 & 0.1163 \\
\hline PE? & 4.86E-09 & 2.50E-09 & $1.940845^{* *}$ & 0.0614 \\
\hline PP? & $1.21 \mathrm{E}-05$ & $1.40 \mathrm{E}-06$ & $8.650753^{*}$ & 0.0000 \\
\hline \multicolumn{5}{|c|}{ Random Effects (Cross) } \\
\hline _LOBAR--C & -4.427045 & & & \\
\hline _LOTENG--C & -0.559428 & & & \\
\hline _LOTIM--C & -6.018447 & & & \\
\hline _SUMBAWA--C & 0.507531 & & & \\
\hline _DOMPU--C & 6.953398 & & & \\
\hline _BIMA--C & 2.996200 & & & \\
\hline _MATARAM--C & 0.547791 & & & \\
\hline & \multicolumn{2}{|c|}{ Effects Specification } & S.D. & Rho \\
\hline Cross-section random & & & 5.051711 & 0.9815 \\
\hline \multicolumn{5}{|c|}{ Weighted Statistics } \\
\hline R-squared & 0.791168 & \multicolumn{2}{|c|}{ Mean dependent var } & 122.6564 \\
\hline Adjusted R-squared & 0.770959 & \multicolumn{2}{|c|}{ S.D. dependent var } & 1.434860 \\
\hline S.E. of regression & 0.686699 & \multicolumn{2}{|c|}{ Sum squared resid } & 14.61822 \\
\hline F-statistic & 39.14830 & \multicolumn{2}{|c|}{ Durbin-Watson stat } & 1.018249 \\
\hline Prob(F-statistic) & 0.000000 & & & \\
\hline \multicolumn{5}{|c|}{ Unweighted Statistics } \\
\hline R-squared & -7.383630 & \multicolumn{2}{|c|}{ Mean dependent var } & 2003.000 \\
\hline Sum squared resid & 586.8541 & \multicolumn{2}{|c|}{ Durbin-Watson stat } & 0.025364 \\
\hline
\end{tabular}

